\title{
Molecular Identification of Lipase Producing Bacteria based on 16S rDNA Sequencing
}

\author{
P. Pallavi*, P. Bhavani, J. Komali and T. Manjusha \\ Department of Microbiology, Government Degree College for Women, Nalgonda, India \\ *Corresponding author
}

\author{
A B S T R A C T
}

\begin{tabular}{|l|}
\hline Ke y w o r d s \\
Molecular, \\
Lipases, \\
Deacetylation, \\
Isolation
\end{tabular}

Lipases or triacyl glycerol acylester hydrolases or carboxyl esterases (E.C 3.1.1.3) that catalyze both hydrolysis and synthesis of esters formed from glycerol. Lipases are currently attracting an enormous attention because of their biotechnological applications. In particular, lipases of microbial origin finding immense applications in various fields as they can catalyze a variety of hydrolytic or synthetic reactions. A bacterial strain isolated from an oil contaminated soil using Nutrient agar medium with $1 \%$ olive oil. The isolated strains were screened for lipolytic activity on tributyrin agar and the lipolytic potential was measured. The strains with lipolytic potential $(\mathrm{R} / \mathrm{r})>2$ were selected and further screened for lipase production on ideal medium. The Lipase assay was carried out by measuring the growth using optical density at regular time intervals of $24 \mathrm{hrs}$, 48hrs and $72 \mathrm{hrs}$ respectively. The selected bacterial strain with maximum lipase production was observed at $48 \mathrm{hrs}, 37 \mathrm{oC}(9.0 \mathrm{EU} / \mathrm{ml})$. In our studies, the best producer of lipase was subjected to molecular identification based on 16S r DNA nucleiotide sequence homology and phylogenetic analysis, a newly isolated indigenous potential lipase producing strain (LP5) was identified as Bacillus subtilis strain Y-IVI.

\section{Introduction}

Lipases (glycerol ester hydrolases, EC 3.1.1.3) are one of the most important classes of industrial enzymes that catalyze the hydrolysis of triglycerides to fatty acids and glycerol (Jager and Reets, 1998; Rajendran and Thangavelu, 2007). They are produced by many bacteria, fungi, plants, animals and are being employed in food, cosmetics, detergents and pharmaceutical industries (Vulfson, 1994; Suk- Jung et al., 2003). Recently, there have been attempts to use lipase for the deacetylation of cephalosporins (Lee et al., 2001). Lipases are known to have certain roles in human pathogenesis and their activity modulators have been suggested as potent pharmaceuticals for the treatment of obesity (Kanwamura et al., 1999; Nonaka et al., 1996; Park, 2001). Lipases perform essential roles in the digestion, transport and processing of dietary lipids (triglycerides, fats, oils) in most living organisms.

Although the existence of lipolytic bacteria is known for many years, our understanding of bacterial lipolysis stems from the fact that most of the studies are with crude enzyme systems. Only few studies have been made with partially purified lipases (Mencher et al., 
1967). In view of the importance of bacterial lipases, in the present investigations an attempt was made to isolate, screen and characterize efficient strains so that they can be employed for commercial production.

\section{Materials and Methods}

\section{Isolation}

The oil contaminated soil samples were collected aseptically and isolations were made by spread plate method using serial dilutions on nutrient agar medium amended with olive oil as substrate. (composition: peptone $5 \mathrm{~g} / \mathrm{l}$; beef extract $3 \mathrm{~g} / \mathrm{l} ; \mathrm{NaCl} 5 \mathrm{~g} / \mathrm{l}$; distilled water 1 liter; olive oil 1\%) and the plates were incubated at $30 \mathrm{oC}$ for 48 hours. The bacterial colonies developed on the medium were isolated and were selected for screening.

The selected strains were maintained on nutrient agar medium amended with $1 \%$ olive oil medium. Isolations were also made from direct oil samples (ground nut oil, coconut oil, palm oil etc.,) by taking $0.1 \mathrm{ml}$ of oil sample and spreading it on to tributyrin agar plates.

\section{Screening}

The isolated strains were screened for lipolytic activity and lipolytic potential (R/r), using tributyrin agar medium and spirit blue agar medium. The strains were spread on tributyrin agar (Collins, 1964; Collins and Lyne, 1980; Limpon et al., 2006) and spirit blue agar medium and incubated for 24 hours at $30 \mathrm{oC}$. Then, the bacterial colonies which formed clear zone around them on the plates were recorded and their lipolytic activity and lipolytic potential was calculated by the formula:

Lipolytic potential $=$ hydrolytic zone diameter / colony diameter.

The strains which had exhibited high lipolytic potential were selected and screened further for efficient lipase production.

The strain was tested for lipase production and assessed first in $25 \mathrm{ml}$ of enrichment medium (peptone-10g/l, beef extract-3g/l, $\mathrm{NaCl}-5 \mathrm{~g} / \mathrm{l}, 1 \%$ olive oil and $\mathrm{pH}-7$ ). After incubation for 24 hours the preculture formed was inoculated into production medium (basal medium) of composition (g/l): starch 20, peptone 20, NH4Cl 3.8, MgSO4 1, K2HPO4 5 , olive oil $1 \%, \mathrm{pH} 7.0$. The culture was then incubated for 72 hours in an orbital shaker at $100 \mathrm{rpm}$ at $30 \mathrm{oC}$. The cells were then harvested by centrifugation at $5000 \mathrm{rpm}$ for $15 \mathrm{~min}$ and the supernatant was used for further assay at regular interval of 24 hours, 48 hours, and 72 hours. Bacterial growth was determined by measuring the absorbance at $550 \mathrm{~nm}$ (Sangiliyandi and Gunasekaran, 1996) and the final $\mathrm{pH}$ of the medium was also determined.

\section{Lipase assay}

The lipase activity in the culture filterate was assayed by titrimetry (Venkateshwarlu and Reddy, 1993). The reaction mixture included $2 \mathrm{ml}$ of enzyme, $5 \mathrm{ml}$ of citrate phosphate buffer $(\mathrm{pH} 8.0), 2 \mathrm{ml}$ of triacetin and was incubated at $37 \mathrm{oC}$ for 3 hours, at the end of incubation the reaction was terminated by adding $10 \mathrm{ml}$ of ethanol and the mixture was titrated against $0.05 \mathrm{M} \quad \mathrm{NaOH}$ using phenolphthalein indicator. The activity of enzyme was expressed in terms of enzyme units. One unit of enzyme activity is defined as the amount of enzyme required to liberate $1 \mu \mathrm{mol}$ of equivalent fatty acid ( $\mathrm{ml} / \mathrm{min}$ ) under the standard assay conditions.

\section{$16 S$ rDNA sequence identification and phylogenetic tree analysis}

Genomic DNA extraction was utilized as a template for the performance of PCR 
amplification for 16S rDNA identification with a set of universal primers that are highly conserved among prokaryotes and could amplify $1,500 \mathrm{bp}$. The universal primers used were as follows: forward and reverse DNA sequencing reaction of PCR amplicon was carried out with $8 \mathrm{~F}$ and $1492 \mathrm{R}$ primers

8F: 5' AGA GTT TGA TCC TGG CTC AG 3' 1492R: 5' ACG GCT ACC TTG TTA CGA CTT 3' using BDT v3.1 cycle sequencing kit on ABI 3730xl genetic analyzer. A DNA homology search was conducted using the Genbank database (http://WWW. ncbi.nih.gov). A phylogenetic tree was constructed using Tree Top phylogenetic Tree prediction software (http://www.genebee. msu.su).

\section{Results and Discussion}

In the present investigations, a large number of bacterial strains were isolated from different oil mill soils. Out of them, four bacterial strains were selected for further screening for their extra cellular enzymatic activity. The lipolytic potential and hydrolytic zone diameter were calculated on tributyrin agar (Table 1). It is evident from the data presented in the table that the highest lipolytic activity was shown by Lp5and its lipolytic potential is 2.6 .

Data presented in table 2 and 3 , reveals that all the four strains of bacteria produced lipase in one or other medium. Lp5 produced maximum lipase $(9.0 \mathrm{Eu} / \mathrm{ml})$ in medium, and had highest growth of OD 0.651 at 48 hours of incubation. All the other strains produced lipase at optimum level at an incubation of 48 hours using the medium. The continuous increasing in production was recorded till 48 hours and later the lipase production decreased gradually so, for the above isolates of bacterial strains lipase production was optimum at 48 hours incubation on medium.

Table.1 Evaluation of lipolytic potential of selected strains

\begin{tabular}{|l|c|c|c|}
\hline Isolate & $\begin{array}{c}\text { Colony } \\
\text { diameter(r)mm }\end{array}$ & $\begin{array}{c}\text { Zone diameter }{ }^{\circledR} \\
\mathbf{m m}\end{array}$ & $\begin{array}{c}\text { Lipolytic } \\
\text { potential(R/r) }\end{array}$ \\
\hline Lp1 & 4.0 & 6.0 & 1.5 \\
\hline Lp3 & 3.0 & 8.0 & 2.6 \\
\hline Lp4 & 4.0 & 8.0 & 2.0 \\
\hline Lp5 & 3.0 & 8.0 & 2.6 \\
\hline
\end{tabular}

Table.2: Bacterial growth on Ideal medium

\begin{tabular}{|l|l|l|l|}
\hline Isolate & \multicolumn{3}{|c|}{ Growth(OD) } \\
& $\mathbf{2 4 h r}$ & $\mathbf{4 8 h h}$ & $\mathbf{7 2 h r}$ \\
\hline Lp1 & 0.193 & 0.527 & 0.682 \\
\hline Lp3 & 0.429 & 0.651 & 0.506 \\
\hline Lp4 & 0.249 & 0.563 & 0.663 \\
\hline Lp5 & 0.375 & 0.603 & 0.712 \\
\hline
\end{tabular}


Fig.1 Phylogenetic tree showing evolutionary relationships of 11 taxa

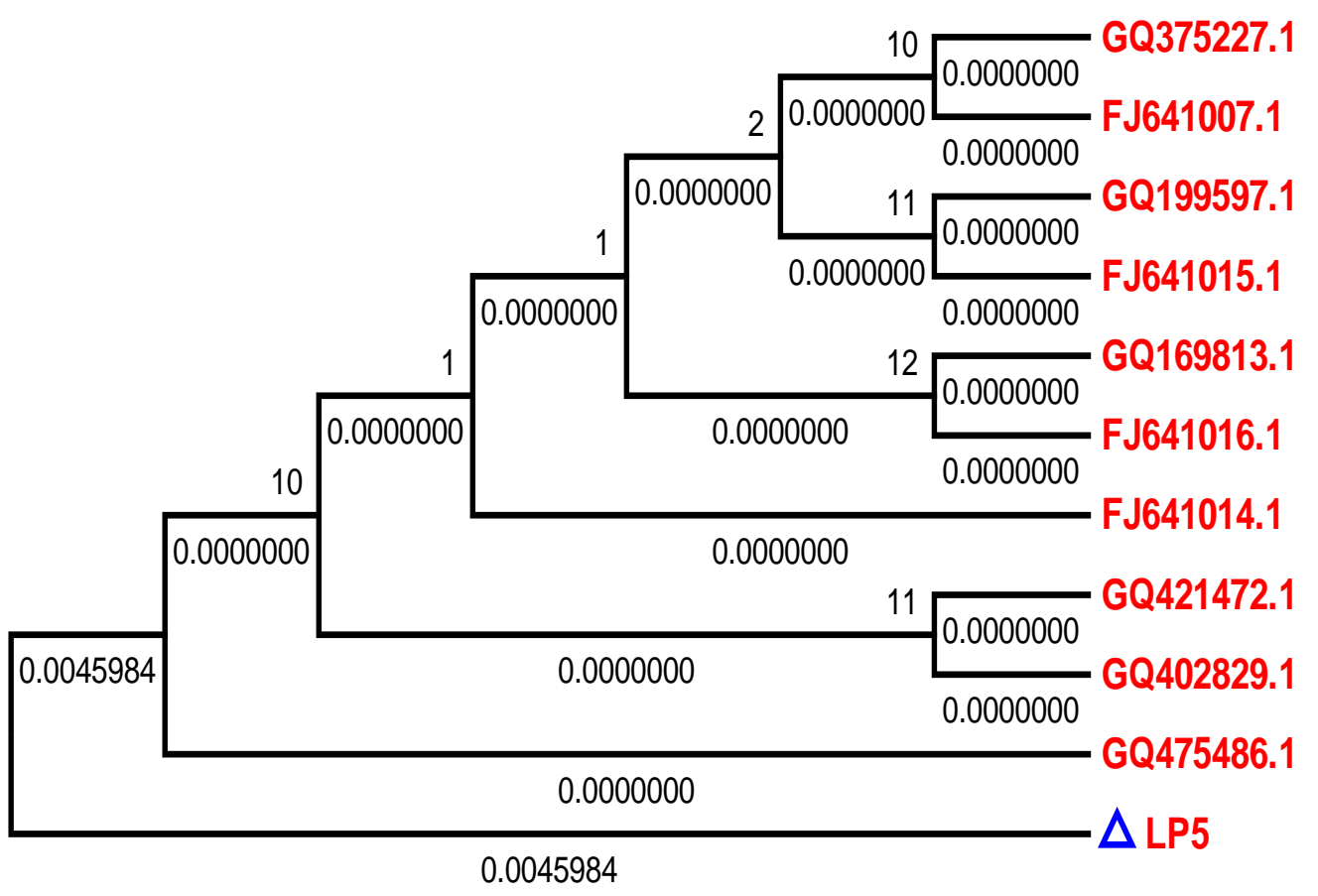

BLAST DATA (Alignment view using combination of NCBI GenBank and RDP databases)

\begin{tabular}{|c|c|c|c|}
\hline Alignment View & ID & $\begin{array}{c}\text { Alignment } \\
\text { Result }\end{array}$ & Description \\
\hline$\square$ & Consensus & 0.96 & Sample LP5 16S rDNA \\
\hline$\square$ & GQ475486.1 & 1.00 & $\begin{array}{l}\text { Bacillus subtilis strain Y-IVI 16S ribosomal RNA } \\
\text { gene }\end{array}$ \\
\hline 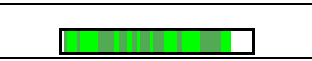 & GQ421472.1 & 0.99 & Bacillus subtilis strain L4 16S ribosomal RNA gene \\
\hline$\square$ & GQ402829.1 & 1.00 & Bacillus sp. G3(2009) 16S ribosomal RNA gene \\
\hline$\square$ & GQ375227.1 & 0.99 & $\begin{array}{l}\text { Bacillus subtilis subsp. subtilis strain CICC } 10076 \\
\text { 16S ribosomal RNA gene }\end{array}$ \\
\hline$\square$ & GQ199597.1 & 0.99 & Bacillus subtilis strain I527 16S ribosomal RNA gene \\
\hline$\square$ & GQ169813.1 & 1.00 & $\begin{array}{l}\text { Bacillus subtilis strain B107 16S ribosomal RNA } \\
\text { gene }\end{array}$ \\
\hline$\square$ & FJ641016.1 & 1.00 & $\begin{array}{l}\text { Bacillus subtilis strain IMAUB1036 16S } \\
\text { ribosomal RNA gene }\end{array}$ \\
\hline$\square$ & FJ641015.1 & 1.00 & $\begin{array}{l}\text { Bacillus subtilis strain IMAUB1035 16S ribosomal } \\
\text { RNA gene }\end{array}$ \\
\hline$\square$ & FJ641014.1 & 1.00 & $\begin{array}{l}\text { Bacillus subtilis strain IMAUB1031 16S ribosomal } \\
\text { RNA gene }\end{array}$ \\
\hline प & FJ641007.1 & 1.00 & $\begin{array}{l}\text { Bacillus subtilis strain IMAUB1018 16S ribosomal } \\
\text { RNA gene }\end{array}$ \\
\hline
\end{tabular}


Table.3: Production of lipase on ideal medium

\begin{tabular}{|l|l|l|l|}
\hline Isolate & \multicolumn{3}{|c|}{$\mathbf{\text { Eu/ml }}$} \\
& $\mathbf{2 4 h \mathbf { 8 h r }}$ & $\mathbf{7 2 h r}$ \\
\hline Lp1 & 2.0 & 6.0 & 0.7 \\
\hline Lp3 & 1.6 & 6.4 & 1.2 \\
\hline Lp4 & 3.2 & 5.0 & 1.7 \\
\hline Lp5 & 5.5 & 9.0 & 0.7 \\
\hline
\end{tabular}

16S rDNA identification and phylogenetic tree analysis

Strain Lp5 was identified as Bacillus subtilis strain Y-IVI sp. 16S ribosomal RNA was employed for identification of the Lp5 strain. The 16S rDNA nucleotide sequence obtained for Lp5. The phylogenetic tree analysis of Lp5 strain was constructed on the basis of comparison of the 16S rDNA sequence of this strain with other Bacillus sp. Strains available in the NCBI Genebank database.

The phylogenetic tree analysis of strain Lp5 was compared with 10 other bacillus sp. Sequences. It evidenced a high degree of homology with Bacillus subtilis strain Y-IVI. The phylogenetic relationship of closely related Bacillus sp. Is depicted in fig. On the basis of its morphological, cultural, biochemical characteristics, 16S rDNA strain Lp5 was identified as Bacillus subtilis strain Y-IVI.

\section{References}

Jaeger, K.E. and Reetz, M.T. 1998. Microbial lipases from versatile tools for biotechnology. Trends in Biotechnol., 16: 369-403.

Mencher, J.R. and Alford, J.A. 1967. Purification and characterization of the lipase of Pseudomonas fragi. J. Gen. Microbiol., 48: 317-328.

Collins, C.H. and Lyne, P.M. 1980. Microbiological methods, 4th Edition Butterworths, London.

Collins, C.H. 1964. Microbiological methods Butterworths, London.

Sangiliyandi, G. and Gunasekaran, P. 1996. Extracellular lipase producing Bacillus licheniformis from an oil mill refinery effluent. Ind. J. Microbiol., 36: 109-110.

Venkateshwarlu, N. and Reddy, S.M. 1993. Production of lipase by five thermophilic fungi. Ind. J. Microbiol., 33(2): 119-124.

Nonaka, Y. 1996. Effects of ebelactone B, La lipase inhibitor, on intestinal fat absorption in the rat. J. Enzyme Inhib., 10: 57-63.

\section{How to cite this article:}

Pallavi, P., P. Bhavani, J. Komali and Manjusha, T. 2017. Molecular Identification of Lipase Producing Bacteria based on 16S rDNA Sequencing. Int.J.Curr.Microbiol.App.Sci. 6(5): 20672071.

doi: https://doi.org/10.20546/ijcmas.2017.605.230 